\title{
HIV Protease Inhibitor Nelfinavir Targets Human DDI2 and Poten- tiates Proteasome Inhibitor-based Chemotherapy
}

\author{
Yuan $\mathrm{Gu}^{1, \#}$, Xin Wang ${ }^{1, \#}$, Yu Wang ${ }^{1, \#}, \mathrm{Jie} \mathrm{Li}^{2}$, Fa-Xing Yu ${ }^{1, *}$ \\ Institutes of Biomedical Sciences, Fudan University, Shanghai, China \\ 2 Large-scale Protein Preparation System, National Facility for Protein Sciences, Shanghai, China \\ \#, These authors contributed equally \\ * Corresponding author: Fa-Xing Yu
}

1 Institute of Pediatrics, Children's Hospital of Fudan University, and the Shanghai Key Laboratory of Medical Epigenetics,

Keywords: protease inhibitor, HIV - 1 protease, anticancer drug, proteasome, multiple myeloma, Nelfinavir, DNA damage inducible 1 homolog 2

\begin{abstract}
Proteasome inhibitors (PIs) are currently used in the clinic to treat cancers such as multiple myeloma (MM). However, cancer cells often rapidly develop drug resistance towards PIs due to a compensatory mechanism mediated by nuclear factor erythroid 2 like 1 (NFE2L1) and aspartic protease DNA damage inducible 1 homolog 2 (DDI2). Following DDI2-mediated cleavage, NFE2L1 is able to induce transcription of virtually all proteasome subunit genes. Under normal condition, cleaved NFE2L1 is constantly degraded by proteasome, whereas in the presence of PIs, it accumulates and induces proteasome synthesis which in turn promotes the development of drug resistance towards PIs. Here, we report that Nelfinavir (NFV), an HIV protease inhibitor, can inhibit DDI2 ac-

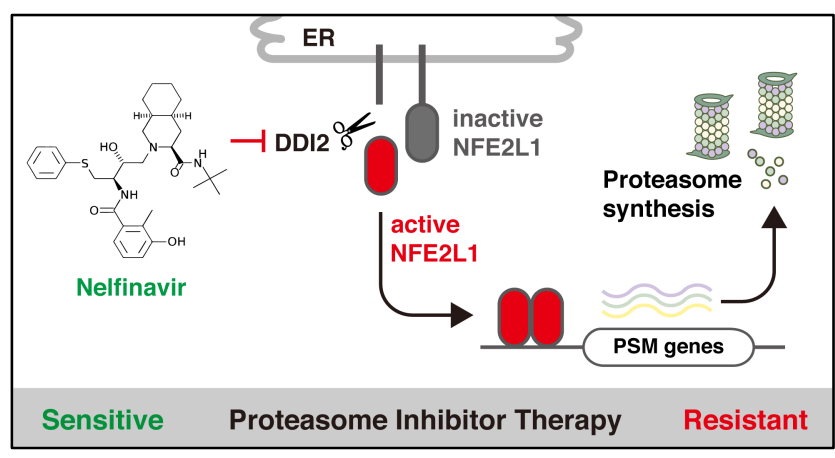
tivity directly. Inhibition of DDI2 by NFV effectively blocks NFE2L1 proteolysis and potentiates cytotoxicity of PIs in cancer cells. Recent clinical evidence indicated that NFV can effectively delay the refractory period of MM patients treated with PI-based therapy. Our finding hence provides a specific molecular mechanism for combinatorial therapy using NFV and PIs for treating MM and probably additional cancers.
\end{abstract}

\section{Introduction}

The ubiquitin-proteasome system (UPS) is a major protein degradation pathway in eukaryotic cells that participates in diverse biological and pathological processes, including immune defense, neuronal disorders, and tumorigenesis ${ }^{1-5}$. In cancer cells, the proteasome is often overloaded with mutant or overexpressed proteins, making it a promising target for anti-cancer therapies ${ }^{3,6-8}$. Several proteasome inhibitors (PIs) have been approved as first-line therapies for multiple myeloma (MM) and mantle cell lymphoma ${ }^{9,10}$. Among them, Bortezomib (BTZ, marketed as Velcade) is a dipeptidyl boronic acid derivative that reversibly targets the active site of the $\beta 5$-subunit of the $20 \mathrm{~S}$ proteasome $^{11}$. While PIs serve as the backbone therapy for MM, most patients relapse and become refractory towards PIs ${ }^{12-16}$. In addition, despite a strong dependence on functional proteasome system, most cancer types, especially solid tumors, are resistant to PIs ${ }^{17,18}$.

The development of resistance to PIs is most-likely dependent on compensatory proteasome synthesis. Nuclear Factor, Erythroid 2 Like 1 (NFE2L1, also known as NRF1 for NFE2Related Factor 1), a CNC-type bZIP family transcription factor, serves as a master regulator for proteasome synthesis. In steady state, NFE2L1 translocates from the endoplasmic reticulum (ER) lumen to the cytoplasm by valosin containing protein ( VCP/p97), and is quickly degraded by proteasome via the ERassociated degradation (ERAD) pathway ${ }^{19}$. In the presence of
PIs, cytosolic NFE2L1 is de-N-glycosylated by N-glycanase 1 (NGLY1) ${ }^{20,21}$, and subsequently cleaved by aspartic protease DNA damage inducible 1 homolog 2 (DDI2) ${ }^{22}$. The cleavage generates a C-terminal fragment of NFE2L1 which retains DNA-binding and transcription-activating properties. In the nuclei, the NFE2L1 C-terminal fragment induces expression of almost all the proteasome subunit genes ${ }^{23,24}$. Newly synthesized proteasomes in turn dilute the efficacy of PIs and reestablish a balanced cellular protein turnover. This molecular strategy is known as the "bounce-back" mechanism for cells to handle stress upon proteasome inhibition ${ }^{19,25}$ (Extended Data Fig. 1a).

To reduce drug resistance towards PI-based chemotherapy, new proteasome synthesis should be minimized, and several enzymes in the "bounce-back" loop may serve as molecular targets. Very recently, it has been shown that NGLY1 inhibitors potentiate cytotoxicity of PIs ${ }^{20,21}$, and inhibition of $\mathrm{VCP} / \mathrm{p} 97$ induces cancer cell death ${ }^{26-28}$. Moreover, DDI2 deficiency can attenuate the transcriptional activity of NFE2L1 and potentiate cytotoxicity of PIs ${ }^{29}$. Compared to $\mathrm{VCP} / \mathrm{p} 97$ and NGLY1, DDI2 is a more specific molecular target, because so far only NFE2L1 and its homolog NFE2L3 have been identified as substrates of DDI2. Hence, a small-molecule inhibitor targeting DDI2 has a great potential to improve PI-based chemotherapy.

In this report, we show that Nelfinavir (NFV), an approved drug for treating HIV infection, can directly inhibit DDI2. Moreover, NFV can effectively block accumulation of active 
A

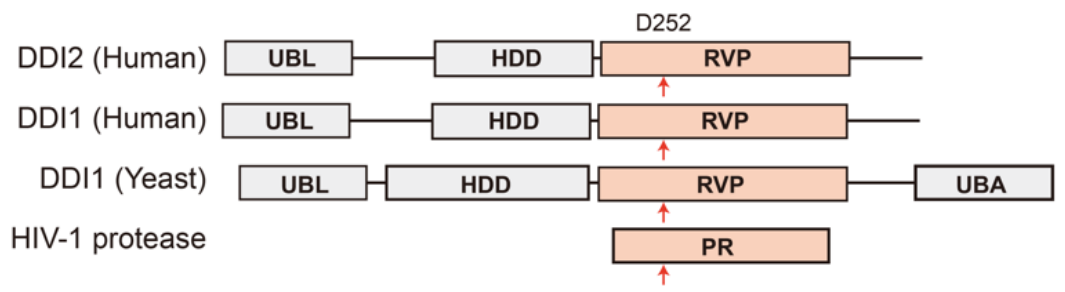

C

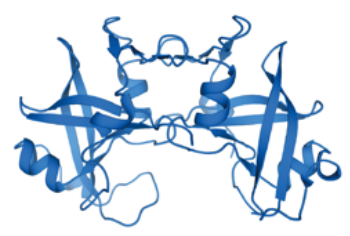

hDDI2 RVP dimer
HIV protease

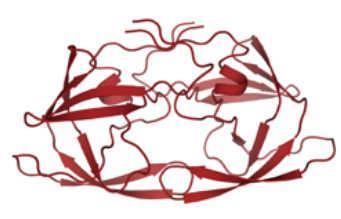

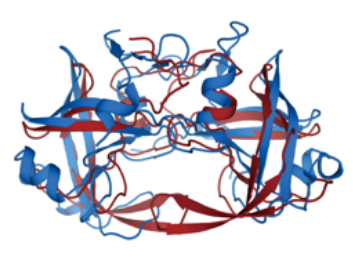

Merge
B

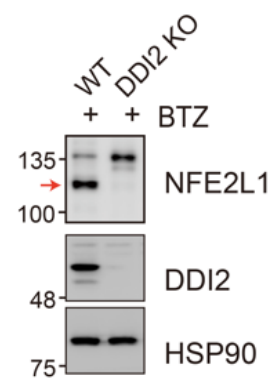

D

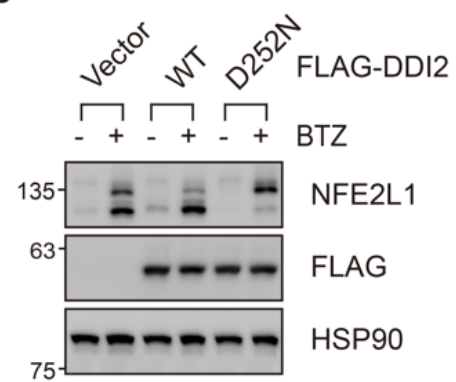

$\mathbf{E}$
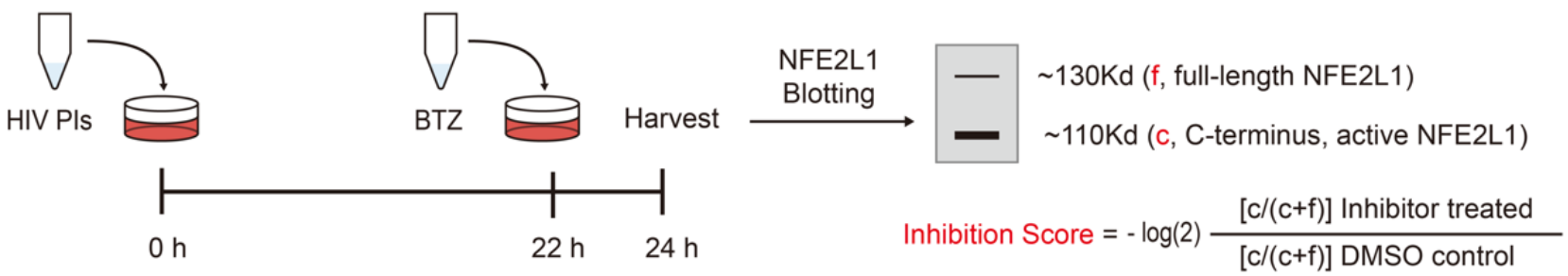

$\mathbf{F}$
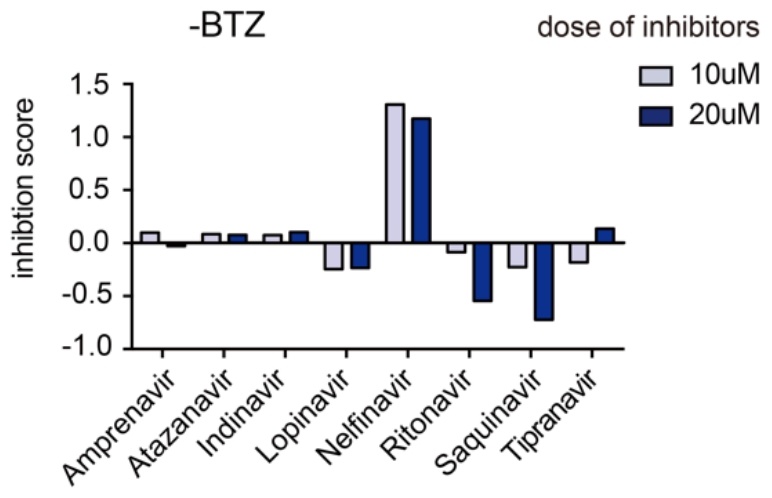

G

H
+ BTZ

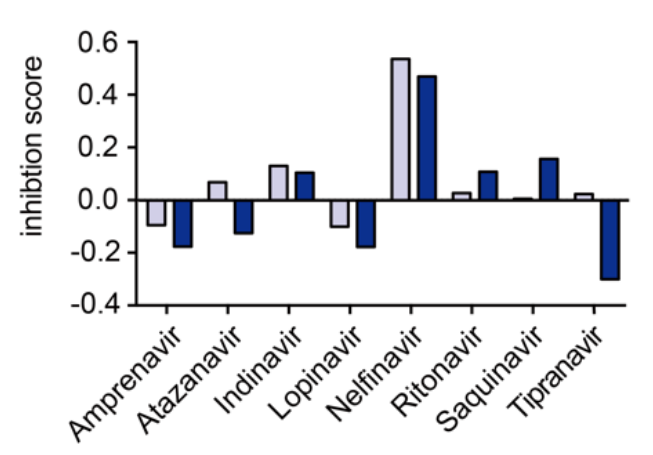

dose of inhibitors

$\square$ 10uM

$\square 20 \mathrm{uM}$

I
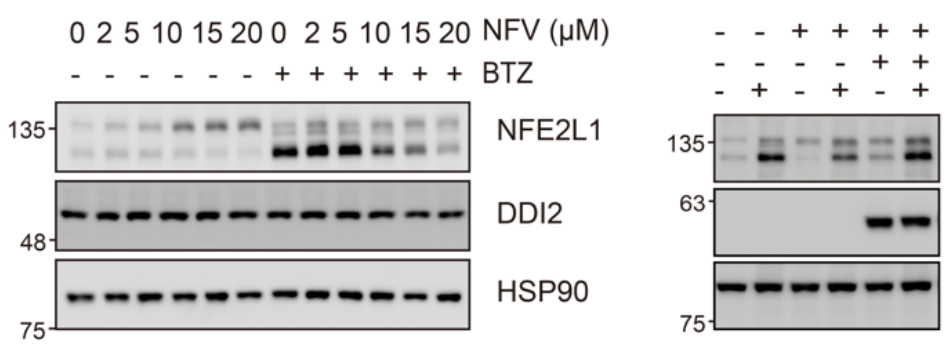

NFV

FLAG-DDI2

NFE2L1

FLAG

HSP9O

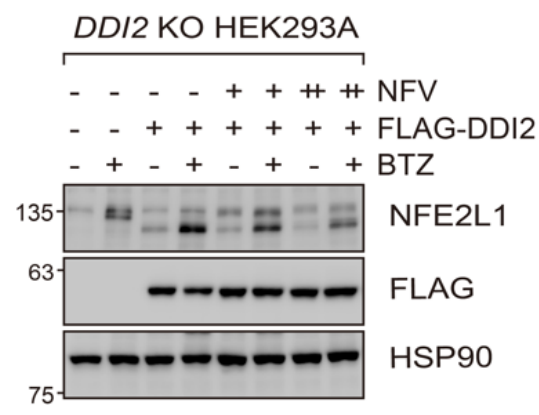

Figure 1. HIV protease inhibitor NFV represses DDI2-mediated NFE2L1 cleavage. (A) Domain organization of DDI2 homologs and HIV protease. UBL: ubiquitin-like domain; UBA: ubiquitin-associated domain; HDD: helical domain; RVP: retroviral protease-like domain; PR: protease. Arrow indicated the active aspartate. (B) Structures of human DDI2 RVP domain (blue) and HIV protease (red). (C) The cleavage 
of NFE2L1 was completely abolished in DDI2 KO cells, arrow indicated the C-terminal fragment of NFE2L1. (D) Overexpression of wildtype(WT) DDI2 promoted NFE2L1 processing while protease-dead DDI2 mutant (D252N) inhibited the processing. BTZ (100nM) was added 2 hours before harvest. (E) Schematic of small-scale screen for DDI2 inhibitors. (F) Relative inhibition of NFE2L1 cleavage by different small molecules. (G) NFV inhibited the processing of NFE2L1 in a dose-dependent manner. HEK293A were treated with different doses of NFV for $24 \mathrm{~h}$. BTZ (100 nM) was added $2 \mathrm{~h}$ before cells were harvested. (H) DDI2 overexpression diluted the efficacy of NFV (10 $\mu \mathrm{M}, 24 \mathrm{~h})$ on NFE2L1 cleavage. BTZ $(100 \mathrm{nM})$ was added $2 \mathrm{~h}$ before cells were harvested. (I) NFV inhibited the activity of ectopically expressed DDI2 in DDI2 KO HEK293A cells. Cells were treated with $10 \mu \mathrm{M}(+)$ or $20 \mu \mathrm{M}(++) \mathrm{NFV}$ for $24 \mathrm{~h}$ followed by BTZ (100 nM) for $2 \mathrm{~h}$.

NFE2L1 in the presence of PIs, and potentiate cytotoxicity of PIs in different cancer cells. The inhibition of DDI2 and NFE2L1 activation by NFV serves as a molecular mechanism underlying the synergistic effects of NFV and PI for combinatorial cancer therapy in different animal models and clinical trials.

\section{Results \\ HIV protease inhibitor NFV represses DDI2-mediated NFE2L1 cleavage.}

Human DDI2 has a ubiquitin-like domain (UBL) at the amino-terminus (N) and a retroviral protease-like domain (RVP) domain near the carboxyl-terminus (C), and the RVP domain is responsible for its protease activity ${ }^{30}$ (Fig. 1a). The RVP domain is highly conserved in DDI2's orthologs and retroviral proteases such as HIV protease ${ }^{30-32}$. When spatially aligned, RVP domain structures of DDI2 and HIV protease largely overlapped, indicating that these two structures shared high degree of similarity (Fig. 1c). Hence, HIV protease inhibitors, many of which directly target the catalytic pocket of HIV protease, may also bind with RVP domain of DDI2 and affect DDI2 protease activity.

To test potential effects of HIV protease inhibitors on DDI2 activity, we utilized NFE2L1 cleavage as a reporter for DDI2 activity (Fig. 1e). The cleavage of NFE2L1 was a faithful readout of DDI2 activity, as it was completely abolished in DDI2 knockout (KO) HEK293A cells and restored upon ectopic DDI2 expression (Fig. 1b, 1i). In the screen, cells were pretreated with HIV protease inhibitors, including Amprenavir, Atazanavira, Indinavir, Lopinavir, NFV, Ritonavir, Saquinavir, or Tipranavir, followed by treatment with BTZ (or without), and the formation of active NFE2L1 by cleavage was monitored by immunoblotting (IB, Fig. 1f, Extended Data Fig. 2a). Among different HIV protease inhibitors, NFV inhibited NFE2L1 processing in a dose-dependent manner, with $20 \mu \mathrm{M}$ NFV showing significant ( $75 \%$ in HEK293A cells) inhibition on NFE2L1 cleavage in various cell types including colorectal cancer cells and MM cell lines (Fig. 1g, Extended Data Fig. 3a-c). Moreover, the efficacy of NFV on NFE2L1 cleavage was largely diluted upon overexpression of DDI2 (Fig. 1h). Recently, NFE2L3, a homolog of NFE2L1, was reported as another DDI2 substrate ${ }^{33}$, and the cleavage of NFE2L3 by DDI2 was also inhibited by NFV (Fig. Extended Data Fig. 3d). Together, these results indicate that NFV can effectively inhibit DDI2 activity.

\section{NFV directly targets human DDI2.}

To determine whether DDI2 is a direct target of NFV, we first conducted cellular thermal shift assay in which ligand-binding would increase a target protein's thermodynamic stability over a range of temperatures ${ }^{34-36}$. Cells were treated with or without NFV for $1 \mathrm{~h}$, and intact cells in suspension were incubated at gradually increasing temperatures. The presence of NFV significantly increased DDI2 protein stability, indicating a direct binding between DDI2 and NFV (Fig. 2a). To gain structural insight of the interaction between NFV and DDI2, we performed computer-aided docking studies. Guided by the structure of NFV-bound HIV protease ${ }^{37}$, we found that NFV could easily fit into the pocket of the DDI2 RVP domain dimer, with binding energies of the chosen clusters for NFV ranging from 9.38 to $-9.46 \mathrm{kcal} / \mathrm{mol}$ (Fig. 2b). The central hydroxyl group of NFV bound to the catalytic aspartate of DDI2, similar to that of HIV protease (Fig. 2b). Hence, NFV most likely interacts with the catalytic center of DDI2 directly and inhibits DDI2 protease activity.

DDI1 is a homolog of DDI2 and is mainly expressed in the testis (www.proteinatlas.org). DDI1 shares high sequence similarity with DDI2, suggesting a role in NFE2L1 processing and potential interaction with NFV (Extended Data Fig. 4a). Indeed, in DDI2 KO cells, ectopically expressed DDI1 fully supported NFE2L1 cleavage. Moreover, NFV inhibited NFE2L1 cleavage in DDI1-reconstituted cells (Extended Data Fig. 4b-d). These results suggest that both DDI1and DDI2 are molecular targets of NFV.

NFV blocks compensatory proteasome synthesis mediated by DDI2 and NFE2L1.

It has been shown previously that DDI2 deficiency is able to switch off NFE2L1 processing and block new proteasome synthesis under proteasome inhibition ${ }^{22,29}$. In the presence of BTZ, NFV effectively repressed active NFE2L1 accumulation, as well as the nuclear translocation of NFE2L1 (Fig. 3a-b). Active NFE2L1 in the nuclei worked as a transcription factor to increase the expression of genes encoding different proteasome subunits. As expected, NFV reduced the expression of proteasome subunit genes under BTZ treatment (Fig. 3c). Together, these lines of evidence indicate that, by inhibiting DDI2 activity and NFE2L1 activation, NFV is effective in disrupting the compensatory signaling (the "bounce-back" mechanism) under proteasome inhibition.

\section{NFV promotes cancer cell death induced by $P I$.}

Since NFV is effective in inhibiting compensatory proteasome synthesis, we next tested if NFV can improve cytotoxicity of PIs towards cancer cells. As determined by CCK8 assays, BTZ alone showed a lethal dose $\left(\mathrm{LD}_{50}\right)$ at $10 \mathrm{nM}$ for HCT116 colorectal cancer cells (Fig. 4a-b). Overexpressing DDI2-D252N, a protease-dead DDI2 mutant, functioned in a dominant negative way (Fig. 1d) and significantly decreased $\mathrm{LD}_{50}$ of BTZ (Fig. 4b). This result confirmed that targeting DDI2 could increase sensitivity of cancer cells to PIs. In line with data from DDI2-D252N overexpression, NFV treatment also decreased $\mathrm{LD}_{50}$ of BTZ. Interestingly and in contrast, DDI2 overexpression significantly increased $\mathrm{LD}_{50}$ of BTZ, and NFV reversed this effect (Fig. 4b), consistent with their effects on NFE2L1 processing (Fig 1i). Hence, high DDI2 activity is protective for cells under proteasome stress, and targeted inhibition of DDI2 by NFV can sensitize cancer cells to death. Meanwhile, NFV treatment showed no further effect on the $\mathrm{LD}_{50}$ of BTZ in 
bioRxiv preprint doi: https://doi.org/10.1101/2020.05.03.075572; this version posted May 5, 2020. The copyright holder for this preprint (which was not certified by peer review) is the author/funder. All rights reserved. No reuse allowed without permission.

A
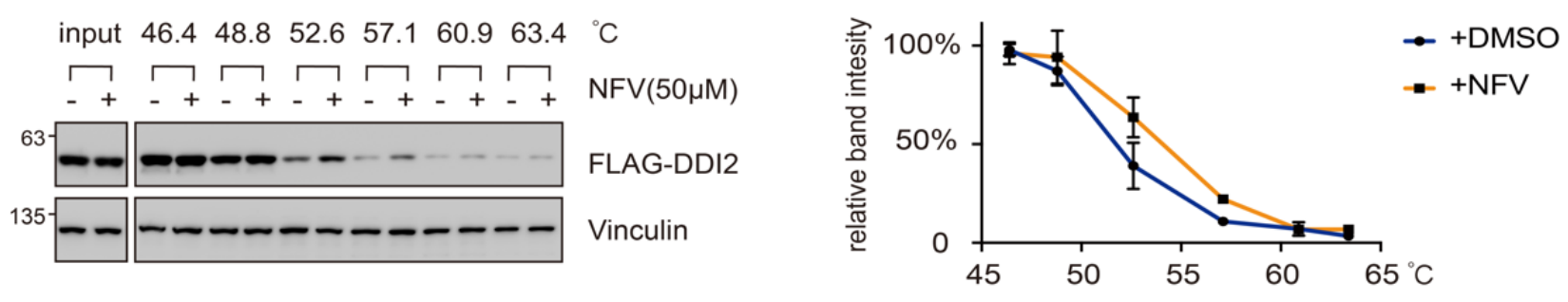

B
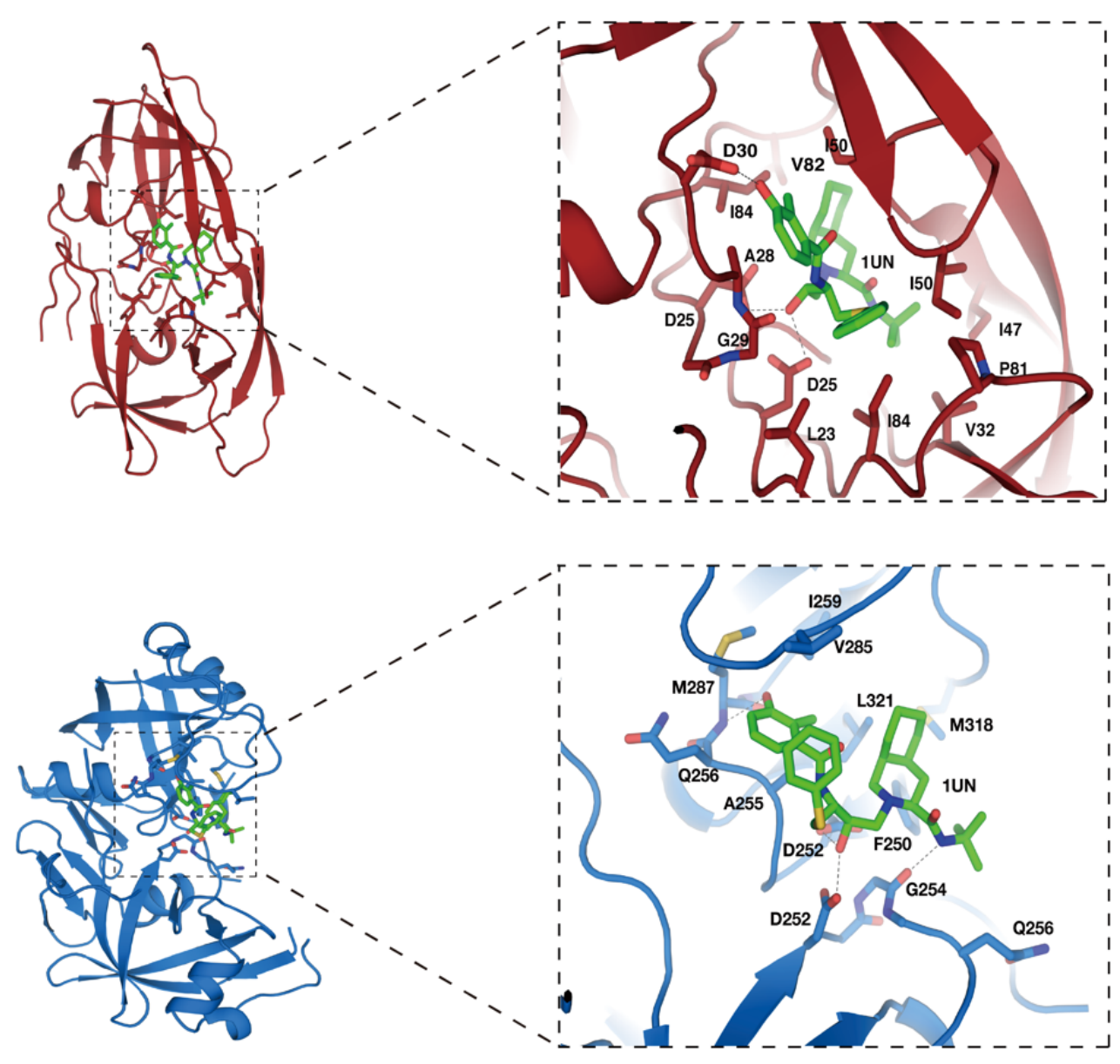

Figure 2. NFV directly targets human DDI2. (A) NFV stabilized DDI2 in a cellular thermal shift assay. HEK293A cells with or without NFV treatment were incubated at different temperatures, and DDI2 turnover was monitored by immunoblotting (left) and quantified (right, melting curve for results of three independent experiments). (B) Docking studies for possible conformations of NFV with human DDI2. Blue: human DDI2 RVP domain. Red: HIV protease. Green: NFV. Note the coordination between NFV with aspartic acids (D252 in DDI2).

DDI2(D252N)-overexpressing HCT116 cells (Fig 4b), indicating that NFV's effect on PI sensitivity was mediated by DDI2 inhibition.

\section{Clinical evidence of NFV in PIs-refractory MM Treat-} ment

NFV is currently used in the clinic as a therapy for HIV infection ${ }^{38}$. Based on our findings, NFV may be repurposed as an anti-cancer agent, especially when used in combination with PIs. Recently, multiple clinical studies indicate that the combination of NFV and BTZ had a great response in the refractory period of MM patients ${ }^{39-41}$ (Table 1), even though a clear molecular mechanism was lacking. Hence, the direct inhibition of DDI2 by NFV, and the resulting repression of NFE2L1 activity and proteasome synthesis, represents a robust mechanism underlying the synergestic effect between NFV and PIs in chemotherapy.

\section{Discussion}

In summary, we have identified NFV as the first small-molecule inhibitor of human DDI2 with a mechanism that likely 
A
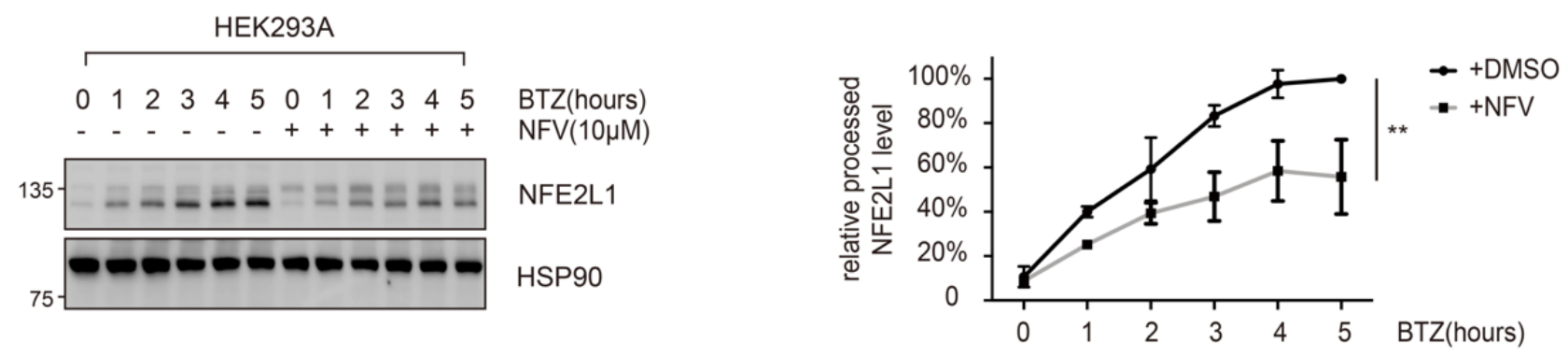

B

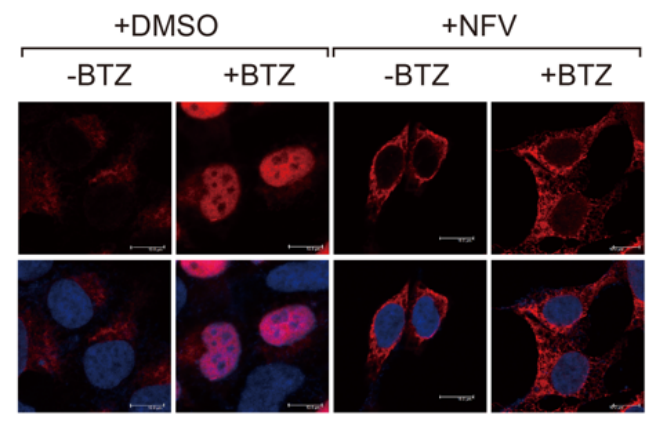

NFE2L1-FLAG DAPI

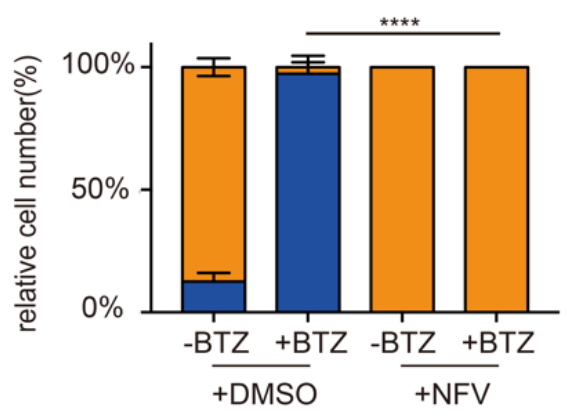

$\square$ Cytosol

$\square$ Nucleus

C

PSMC4
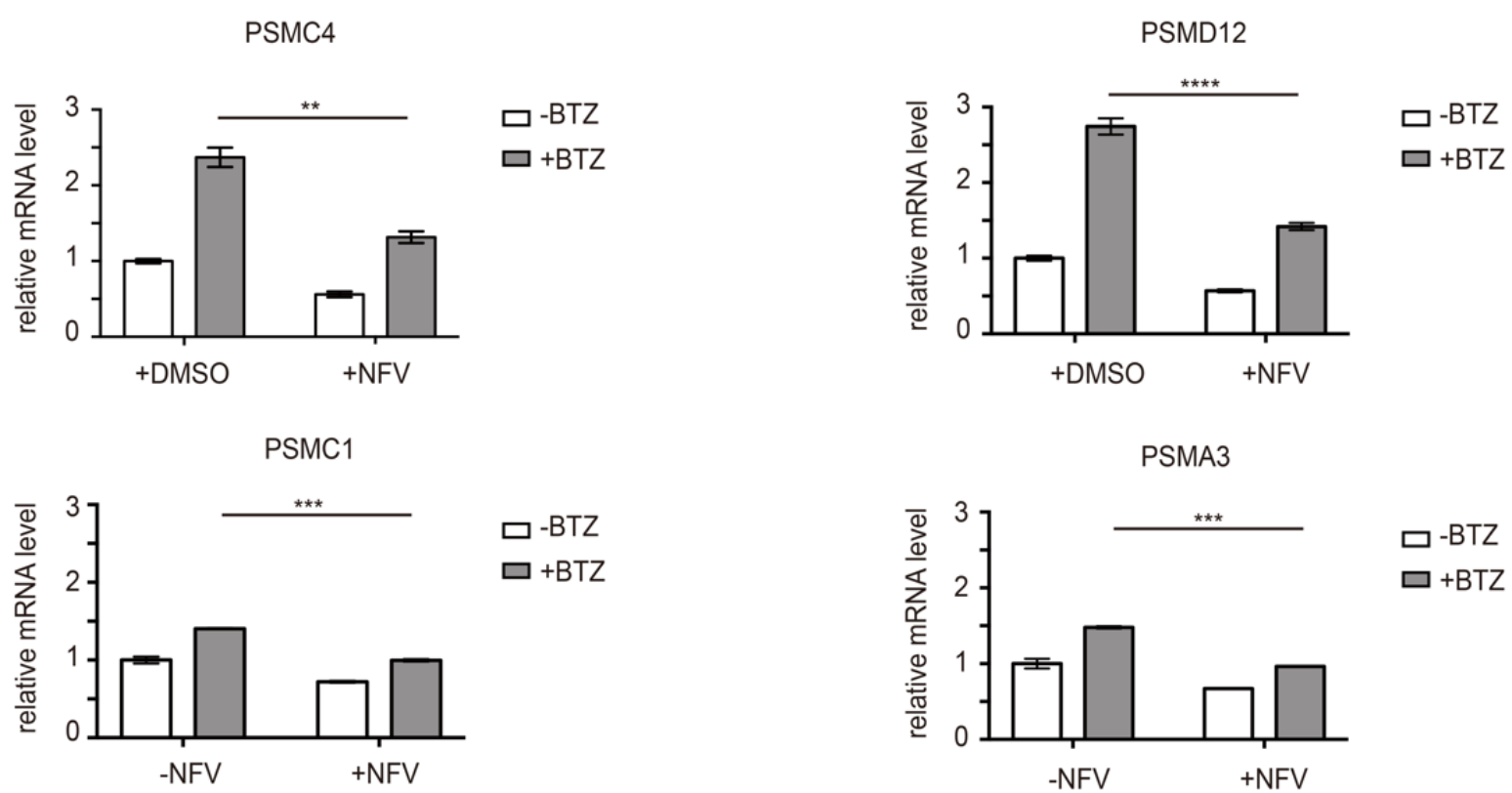

Figure 3. NFV blocks compensatory proteasome synthesis mediated by DDI2 and NFE2L1. (A) NFV delayed the accumulation of processed NFE2L1 under proteasome inhibition. HEK293A cells were treated with $10 \mu \mathrm{M}$ NFV or DMSO for $24 \mathrm{~h}$. BTZ (100 nM) was added for the indicated times before cells were harvested. Cleavage of NEF2L1 were determined by immunoblotting and quantified (right, summary of three independent experiments). (B) NFV blocked nuclear translocation of NFE2L1. HEK293A cell were transfected with NFE2L1 with FLAG tag at C-terminus, and subcellular localization was determined by immunofluorescence using FLAG antibody. Cells with cytoplasmic or nuclear NFE2L1-FLAG staining were counted (right). (C) The mRNA expression of proteasome subunit genes was repressed by NFV. The mRNA levels of HCT116 cells with or without NFV treatment $(10 \mu \mathrm{M}, 24 \mathrm{~h})$ or BTZ treatment $(100 \mathrm{~nm}, 12 \mathrm{~h})$ were determined by quantitative PCR, and normalized by GAPDH mRNA levels. Mean and standard error were presented $\left(* \mathrm{p}<0.05,{ }^{* *} \mathrm{p}<0.005, * * * \mathrm{p}<0.0005\right.$, $* * * * \mathrm{p}<0.00005, \mathrm{~ns}=$ not significant; $\mathrm{n}=3$; $\mathrm{t}$ test).

involves direct interaction with the catalytic center of DDI2. The inhibition of DDI 2 by NFV blocks cleavage and activation of NFE2L1 upon proteasome inhibition, and represses compensatory proteasome synthesis. Insufficient proteasome activity 
A
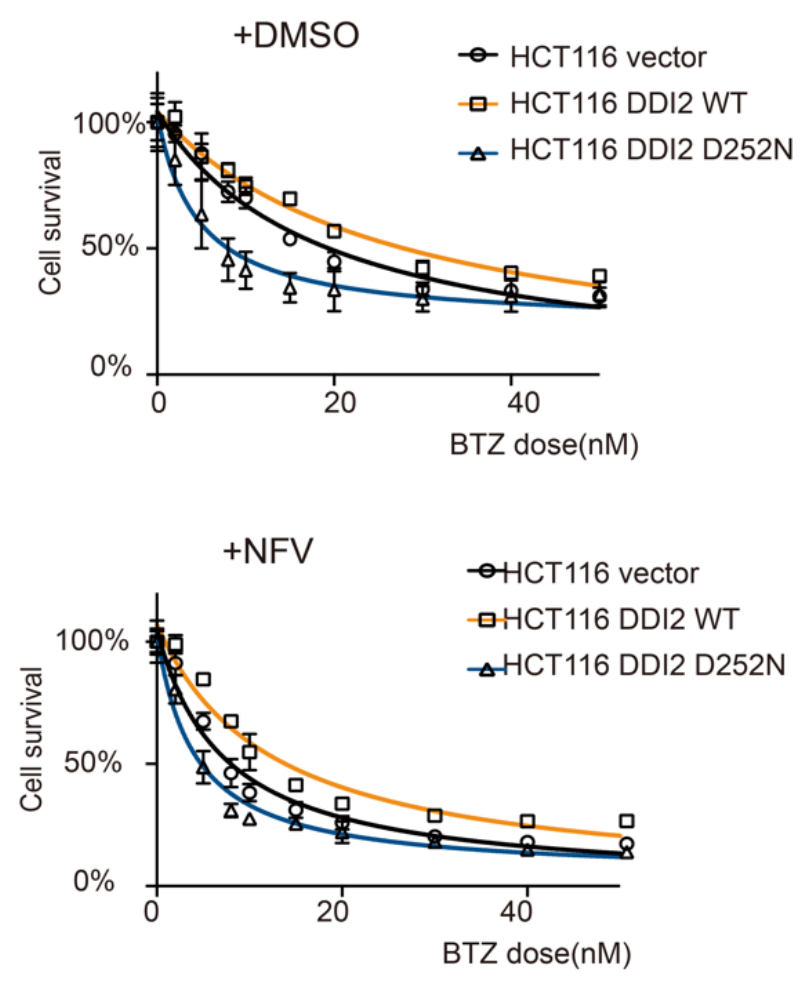

B

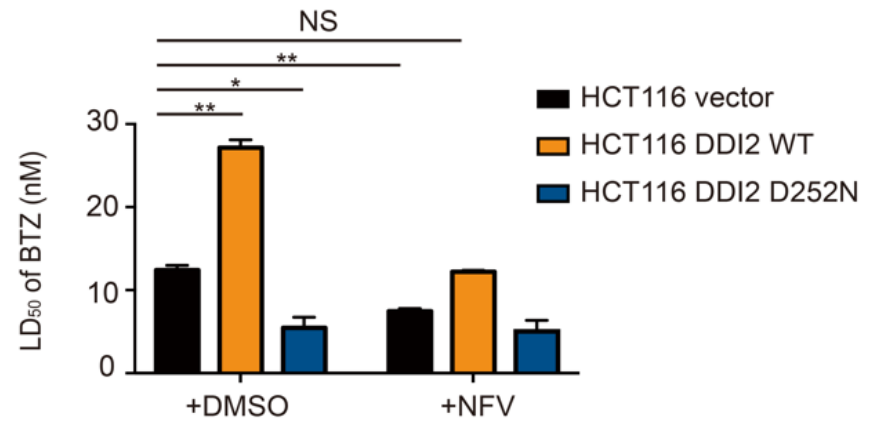

C
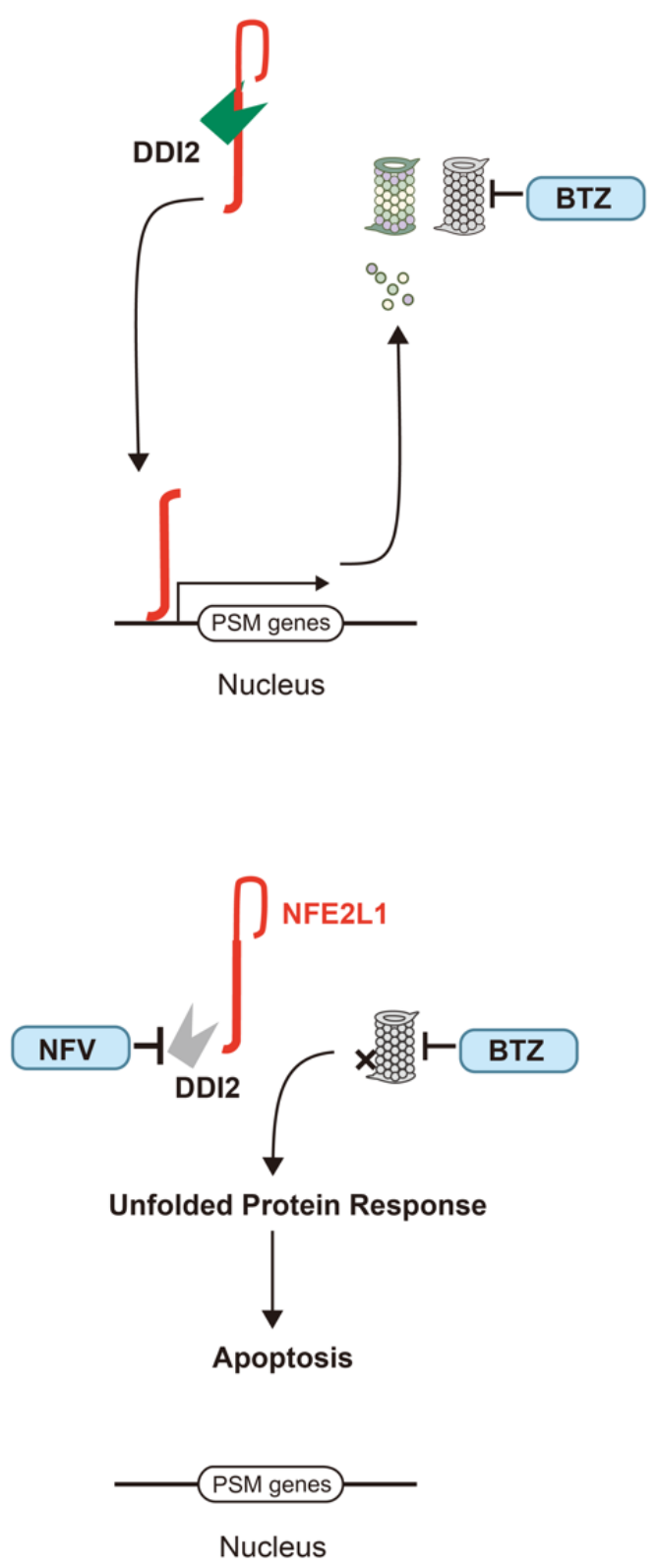

Figure 4. NFV promotes cancer cell death induced by PI. (A) NFV and BTZ synergistically promoted cell death. Control, DDI2overexpressing, or DDI2 D252N- expressing cells were treated with different doses of BTZ together with DMSO or $10 \mu \mathrm{M}$ of NFV for 24 $\mathrm{h}$, survived cells were determined by CCK8 assay. (B) LD 50 of different groups were calculated according the survival curve in (A). Mean and standard error were presented $(* \mathrm{p}<0.05, * * \mathrm{p}<0.005$, ns: not significant, $\mathrm{n}=3, \mathrm{t}$ test). (C) A proposed model of NFV and PI (BTZ) combinatorial therapy.

may cause accumulation of defective proteins and lead to cell death (Fig. 4c). Indeed, NFV and PIs have shown synergistic effects in killing cancer cells in vitro and overcoming drug resistance in refractory period of MM patients clinically. Hence, our study provides a novel molecular mechanism for the clinical efficacy of NFV and BTZ combinatorial cancer therapy.

Our results indicate that NFV may serve as a lead compound for the development of more potent inhibitors of DDI2. However, our in silico modeling of the interaction between NFV and the catalytic center of DDI2 is mainly based on the structural information of HIV protease bound with NFV. Whereas, among different HIV protease inhibitors tested, only NFV showed potent inhibitory effect on DDI2 activity, suggesting some differnces between DDI2 and HIV protease. In the future, a crystal strucute of DDI2 bound with NFV would give more insights regarding to the refinement of DDI2 inhibitors.

The clinical effect of NFV in conjunction with BTZ is currently tested on MM patients. Our work indicates that DDI2 activity serves as a protective factor for cancer cells under proteasome stress, so cancers with high DDI2 expression, such as Esophageal Carcinoma, Acute Myeloid Leukemia, and Esophageal Carcinoma, may also be sensitive to NFV and PI 
Table 1. Clinical evidence of NFV in PIs-refractory MM Treatment.

TRIAL IDENTIFIER PHASE STATUS STUDY TITLE CONDITIONS

INTERVENTION RESPONSE REFERENCE

\begin{tabular}{|c|c|c|c|c|c|c|c|}
\hline NCT01164709 & 1 & $\begin{array}{l}\text { Com- } \\
\text { pleted }\end{array}$ & $\begin{array}{l}\text { Nelfinavir Me- } \\
\text { sylate and Borte- } \\
\text { zomib in Treat- } \\
\text { ing Patients with } \\
\text { Relapsed or Pro- } \\
\text { gressive Ad- } \\
\text { vanced Hemato- } \\
\text { logic Cancer }\end{array}$ & $\begin{array}{l}\text { Leukemia, Lym- } \\
\text { phoma, Mature } \\
\text { T-cell and NK- } \\
\text { cell Neoplasms } \\
\text { and Multiple } \\
\text { Myeloma and } \\
\text { Plasma Cell Ne- } \\
\text { oplasm; Re- } \\
\text { lapsed or Pro- } \\
\text { gressive }\end{array}$ & $\begin{array}{l}\text { NFV+ } \\
\text { BTZ }\end{array}$ & $\begin{array}{l}83 \% \quad \text { ORR, } \\
50 \% \text { PR, 33\% } \\
\text { MR* }\end{array}$ & $\begin{array}{l}\text { Driessen et } \\
\text { al., } 2016\end{array}$ \\
\hline NCT02188537 & 2 & $\begin{array}{l}\text { Com- } \\
\text { pleted }\end{array}$ & $\begin{array}{l}\text { Nelfinavir as } \\
\text { Bortezomib-sen- } \\
\text { sitizing Drug in } \\
\text { Patients with } \\
\text { Proteasome In- } \\
\text { hibitor-nonre- } \\
\text { sponsive Mye- } \\
\text { loma }\end{array}$ & $\begin{array}{l}\text { Myeloma; Pro- } \\
\text { teasome Inhibi- } \\
\text { tor-nonrespon- } \\
\text { sive }\end{array}$ & $\begin{array}{l}\mathrm{NFV}+ \\
\mathrm{BTZ}+ \\
\text { dexamethasone }\end{array}$ & $\begin{array}{ll}74 \% & \text { ORR, } \\
15 \% & \text { VGPR, } \\
50 \% & \text { PR, } 9 \% \\
\text { MR } & \end{array}$ & $\begin{array}{l}\text { Driessen } \\
\text { al., } 2018\end{array}$ \\
\hline NCT01555281 & $1 / 2$ & $\begin{array}{l}\text { Active, } \\
\text { not re- } \\
\text { cruiting }\end{array}$ & $\begin{array}{l}\text { Nelfinavir and } \\
\text { Lenalido- } \\
\text { mide/Dexame- } \\
\text { thasone in Pro- } \\
\text { gressive Multi- } \\
\text { ple Myeloma }\end{array}$ & $\begin{array}{l}\text { Multiple Mye- } \\
\text { loma; lenalido- } \\
\text { mide-refractory }\end{array}$ & $\begin{array}{l}\mathrm{NFV}+ \\
\text { Lenalidomide }+ \\
\text { dexamethasone }\end{array}$ & $\begin{array}{l}55 \% \quad \text { ORR, } \\
10 \% \text { VGPR, } \\
21 \% \text { PR, } 24 \% \\
M R\end{array}$ & $\begin{array}{l}\text { Hitz et al., } \\
2019\end{array}$ \\
\hline
\end{tabular}

*Extension cohort with 6 patients. MM, multiple myeloma; MR, minimal remission; ORR, objective response rate; PI, proteasome inhibitor; PR, partial response; VGPR, very good partial response.

combinatorial therapy (Extended Data Fig. 5a). Hence, the NFV and BTZ combinatorial therapy may also effective in treating some solid tumors with high DDI2 activity.

\section{Experimental procedures \\ DNA constructs}

Human NFE2L1 and DDI2 cDNAs were cloned using total RNA extracted from HEK293A cells. Primers used were shown in extended data table 1. Human DDI1 cDNA was synthesized by Genewiz, Suzhou, China. PCR was performed using PrimeSTAR Max DNA polymerase (Takara Bio, Shiga, Japan). Amplified fragments were subcloned into pLVX lentiviral vector and all plasmids were confirmed by Sanger sequencing.

\section{Cell culture and transfection}

HEK293A, HEK293T, HCT116 and HCT15 cells were cultured in DMEM (Corning) containing 5\% FBS (Gibco) and 50 $\mu \mathrm{g} / \mathrm{mL}$ penicillin/streptomycin (P/S). RPMI8226 cells were cultured in RPMI1640 (Corning) containing 10\% FBS (Gibco) and $50 \mu \mathrm{g} / \mathrm{mL}$ penicillin/streptomycin $(\mathrm{P} / \mathrm{S})$. All cell lines were maintained at $37^{\circ} \mathrm{C}$ with $5 \% \mathrm{CO} 2$. Cells were transfected with plasmid DNA using PolyJet DNA In Vitro Transfection Reagent (Signagen Laboratories, Gaithersburg, USA) according to manufacturer's instructions.

\section{Chemicals}

The following chemicals were used in this study. HIV protease inhibitors including Amprenavir, Atazanavira, Indinavir, Lopinavir, NFV, Ritonavir, Saquinavir, Tipranavir and proteasome inhibitor BTZ were either obtained from the Selleck protease inhibitor kit or purchased separately. Large package of NFV Mesylate was purchased from MCE.

\section{Immunoblotting}

Immunoblotting was performed using standard protocol. The following primary antibodies were used in Immunoblotting: Vinculin (CST, E1E9V), NFE2L1(CST, D5B10), FLAG-HRP (Sigma, A8592), HSP90(BD, 610418). Vinculin and NFE2L1 were diluted 1:1000 while the other two were diluted 1:10000 in TBST containing 5\% BSA. Data were quantified using Image J software.

\section{Immunofluorescence}

HEK293A cells stably overexpressing NFE2L1-flag were seeded on coverslips. After treatment, cells were fixed with $4 \%$ paraformaldehyde-PBS for $10 \mathrm{~min}$ and permeabilized with $0.1 \%$ Triton X-100 in TBS. After blocking in 3\% BSA and 3\% goat serum in PBS for $1 \mathrm{~h}$, cells were incubated with FLAG antibody (CST, D6W5B) overnight at $4^{\circ} \mathrm{C}$. After three washes with PBS, cells were incubated with Alexa Fluor 488- or 555-conjugated secondary antibodies (Invitrogen, 1:1000 diluted) for $1 \mathrm{~h}$ at room temperature. Slides were then washed three times and mounted. Images were captured using Olympus confocal microscopy.

\section{Cellular Thermal Shift Assay}

Cellular thermal shift assay was conducted according to the protocol as previously described ${ }^{34}$. HEK293A cells stably expressing FLAG-DDI2 were treated with $50 \mu \mathrm{M}$ NFV or DMSO 
for $1 \mathrm{~h}$, and cells were collected and washed with PBS buffer three times to avoid excess compound residue. Cells in suspension were equally dispensed into $0.2 \mathrm{ml}$ PCR tubes $(3$ million cells per tube), incubated at preset temperatures for $3 \mathrm{~min}$ on a PCR instrument, and freeze-thawed twice using liquid nitrogen. Samples were centrifuged and the supernatants were analyzed by immunoblotting. All experiments were performed in triplicates.

\section{Docking studies for possible conformations of NFV with} human DDI2

To gain structural understanding and visualization of the interaction between NFV and hDDI2, docking studies were performed using Autodock $4{ }^{42}$. The hDDI2 structure was prepared using previously determined structure of DDI2 (from Gln232 to Glu328, PDB No. 4RGH). All bound waters were removed and then added for hydrogens. All partial atomic charges were assigned automatically using AutoDockTools (ADT). The coordinates of NFV were generated from the structure of HIV-1 protease co-crystallized with NFV (PDB No. 1OHR). The hydrogen atoms and Gasteiger charges were then assigned to the ligand using ADT. The interaction was modeled with the Lamarckian genetic algorithm. The clusters with lower energies and reasonable conformations were chosen as solution. The binding energies of the chosen clusters for NFV ranged from -9.38 to -9.46 $\mathrm{kcal} / \mathrm{mol}$. The orientation of NFV was further confirmed using LeDock (data not shown) ${ }^{43}$.

\section{Quantitative RT-PCR}

Total RNA was extracted using the Takara MiniBEST universal RNA Extraction kit (Takara Bio, Shiga, Japan). cDNA was generated using the TransScript First-Strand cDNA synthesis kit (TransGen Biotech, Beijing, China), and quantitative qPCR was conducted using SYBR Green qPCR Master Mix (Takara Bio, Shiga, Japan) on a 7500 Real-Time PCR systems (Applied Biosystems). Relative abundance of mRNA was calculated by normalization to GAPDH mRNA. Primers used are listed in extended data table 2.

\section{CCK8 cytotoxic assay}

CCK8 cytotoxic assay was conducted by CCK-8 Cell Counting Kit (Yeasen, Shanghai, China) according to manufacturer's instructions. 10,000 HCT116 cells were seeded on 96-well plates. Cell were treated with different doses of drug for $24 \mathrm{~h}$ before analysis, and DMSO was used as control.

\section{ASSOCIATED CONTENT}

\section{Supporting Information}

Supplementary tables and figures are included in the end of this PDF

\section{AUTHOR INFORMATION}

\section{Corresponding Author}

* fxyu@fudan.edu.cn

\section{Author Contributions}

G. Y., and F.X. Y. designed the experiments, analyzed data, and wrote the manuscript. G. Y., X. W., Y. W., and J. Li performed experiments and analyzed data.

\section{ACKNOWLEDGMENT}

This study is supported by grants from the National Natural Science Foundation of China (81772965), the National Key R\&D program of China (2018YFA0800304), Science and Technology Commission of Shanghai Municipality (19JC1411100), and Shanghai Municipal Commission of Health and Family Planning (2017BR018) to FXY.

\section{ABBREVIATIONS}

DDI2, DNA damage inducible 1 homolog 2; NFE2L1, nuclear factor erythroid 2 like 1; NFE2L3, nuclear factor erythroid 2 like 3; NGLY1, N-glycanase 1; P97/VCP, valosin containing protein.

\section{REFERENCES}

(1) Ciechanover, A. The ubiquitin-proteasome proteolytic pathway. Cell 1994, 79 (1), 13.

(2) Evan, G. I.; Vousden, K. H. Proliferation, cell cycle and apoptosis in cancer. Nature 2001, 411 (6835), 342.

(3) Goldberg, A. L. Functions of the proteasome: from protein degradation and immune surveillance to cancer therapy. Biochem Soc Trans 2007, 35 (Pt 1), 12.

(4) Rock, K. L.; Gramm, C.; Rothstein, L.; Clark, K.; Stein, R.; Dick, L.; Hwang, D.; Goldberg, A. L. Inhibitors of the proteasome block the degradation of most cell proteins and the generation of peptides presented on MHC class I molecules. Cell 1994, 78 (5), 761.

(5) Schroder, M.; Kaufman, R. J. The mammalian unfolded protein response. Annu Rev Biochem 2005, 74, 739.

(6) Adams, J. The proteasome: a suitable antineoplastic target. Nat Rev Cancer 2004, 4 (5), 349.

(7) Adams, J.; Palombella, V. J.; Sausville, E. A.; Johnson, J.; Destree, A.; Lazarus, D. D.; Maas, J.; Pien, C. S.; Prakash, S.; Elliott, P. J. Proteasome inhibitors: a novel class of potent and effective antitumor agents. Cancer Res 1999, 59 (11), 2615.

(8) Deshaies, R. J. Proteotoxic crisis, the ubiquitin-proteasome system, and cancer therapy. BMC Biol 2014, 12, 94.

(9) Bazarbachi, A. H.; Al Hamed, R.; Malard, F.; Harousseau, J. L.; Mohty, M. Relapsed refractory multiple myeloma: a comprehensive overview. Leukemia 2019, 33 (10), 2343.

(10) Gandolfi, S.; Laubach, J. P.; Hideshima, T.; Chauhan, D.; Anderson, K. C.; Richardson, P. G. The proteasome and proteasome inhibitors in multiple myeloma. Cancer Metastasis Rev 2017, 36 (4), 561.

(11) Teicher, B. A.; Ara, G.; Herbst, R.; Palombella, V. J.; Adams, J. The proteasome inhibitor PS-341 in cancer therapy. Clin Cancer Res 1999, 5 (9), 2638.

(12) Badros, A.; Burger, A. M.; Philip, S.; Niesvizky, R.; Kolla, S. S.; Goloubeva, O.; Harris, C.; Zwiebel, J.; Wright, J. J.; EspinozaDelgado, I.et al. Phase I study of vorinostat in combination with bortezomib for relapsed and refractory multiple myeloma. Clin Cancer Res 2009, 15 (16), 5250.

(13) Fisher, R. I.; Bernstein, S. H.; Kahl, B. S.; Djulbegovic, B.; Robertson, M. J.; de Vos, S.; Epner, E.; Krishnan, A.; Leonard, J. P.; Lonial, S.et al. Multicenter phase II study of bortezomib in patients with relapsed or refractory mantle cell lymphoma. J Clin Oncol 2006, 24 (30), 4867.

(14) Jagannath, S.; Barlogie, B.; Berenson, J.; Siegel, D.; Irwin, D.; Richardson, P. G.; Niesvizky, R.; Alexanian, R.; Limentani, S. A.; Alsina, M.et al. A phase 2 study of two doses of bortezomib in relapsed or refractory myeloma. Br J Haematol 2004, 127 (2), 165.

(15) Jagannath, S.; Barlogie, B.; Berenson, J. R.; Singhal, S.; Alexanian, R.; Srkalovic, G.; Orlowski, R. Z.; Richardson, P. G.; Anderson, J.; Nix, D.et al. Bortezomib in recurrent and/or refractory multiple myeloma. Initial clinical experience in patients with impared renal function. Cancer 2005, 103 (6), 1195.

(16) Lonial, S.; Waller, E. K.; Richardson, P. G.; Jagannath, S.; Orlowski, R. Z.; Giver, C. R.; Jaye, D. L.; Francis, D.; Giusti, S.; Torre, C.et al. Risk factors and kinetics of thrombocytopenia associated with bortezomib for relapsed, refractory multiple myeloma. Blood 2005, 106 (12), 3777. 
bioRxiv preprint doi: https://doi.org/10.1101/2020.05.03.075572; this version posted May 5, 2020. The copyright holder for this preprint (which was not certified by peer review) is the author/funder. All rights reserved. No reuse allowed without permission.

(17) Huang, Z.; Wu, Y.; Zhou, X.; Xu, J.; Zhu, W.; Shu, Y.; Liu, P. Efficacy of therapy with bortezomib in solid tumors: a review based on 32 clinical trials. Future Oncol 2014, 10 (10), 1795.

(18) Manasanch, E. E.; Orlowski, R. Z. Proteasome inhibitors in cancer therapy. Nat Rev Clin Oncol 2017, 14 (7), 417.

(19) Radhakrishnan, S. K.; den Besten, W.; Deshaies, R. J. p97dependent retrotranslocation and proteolytic processing govern formation of active Nrf1 upon proteasome inhibition. Elife 2014, 3, $\mathrm{e} 01856$.

(20) Huang, C.; Harada, Y.; Hosomi, A.; Masahara-Negishi, Y.; Seino, J.; Fujihira, H.; Funakoshi, Y.; Suzuki, T.; Dohmae, N.; Suzuki, $\mathrm{T}$. Endo-beta-N-acetylglucosaminidase forms N-GlcNAc protein aggregates during ER-associated degradation in Ngly1-defective cells. Proc Natl Acad Sci U S A 2015, 112 (5), 1398.

(21) Tomlin, F. M.; Gerling-Driessen, U. I. M.; Liu, Y. C.; Flynn, R. A.; Vangala, J. R.; Lentz, C. S.; Clauder-Muenster, S.; Jakob, P.; Mueller, W. F.; Ordonez-Rueda, D.et al. Inhibition of NGLY1 Inactivates the Transcription Factor Nrf1 and Potentiates Proteasome Inhibitor Cytotoxicity. ACS Cent Sci 2017, 3 (11), 1143.

(22) Koizumi, S.; Irie, T.; Hirayama, S.; Sakurai, Y.; Yashiroda, H.; Naguro, I.; Ichijo, H.; Hamazaki, J.; Murata, S. The aspartyl protease DDI2 activates Nrf1 to compensate for proteasome dysfunction. Elife 2016, 5 .

(23) Sha, Z.; Goldberg, A. L. Proteasome-mediated processing of Nrf1 is essential for coordinate induction of all proteasome subunits and p97. Curr Biol 2014, 24 (14), 1573.

(24) Steffen, J.; Seeger, M.; Koch, A.; Kruger, E. Proteasomal degradation is transcriptionally controlled by TCF11 via an ERADdependent feedback loop. Mol Cell 2010, 40 (1), 147.

(25) Yuan, J.; Zhang, S.; Zhang, Y. Nrf1 is paved as a new strategic avenue to prevent and treat cancer, neurodegenerative and other diseases. Toxicol Appl Pharmacol 2018, 360, 273.

(26) Magnaghi, P.; D'Alessio, R.; Valsasina, B.; Avanzi, N.; Rizzi, S.; Asa, D.; Gasparri, F.; Cozzi, L.; Cucchi, U.; Orrenius, C.et al. Covalent and allosteric inhibitors of the ATPase $\mathrm{VCP} / \mathrm{p} 97$ induce cancer cell death. Nat Chem Biol 2013, 9 (9), 548.

(27) Segura-Cabrera, A.; Tripathi, R.; Zhang, X.; Gui, L.; Chou, T. F.; Komurov, K. A structure- and chemical genomics-based approach for repositioning of drugs against VCP/p97 ATPase. Sci Rep 2017, 7, 44912.

(28) Vekaria, P. H.; Home, T.; Weir, S.; Schoenen, F. J.; Rao, R. Targeting p97 to Disrupt Protein Homeostasis in Cancer. Front Oncol 2016, $6,181$.

(29) Northrop, A.; Vangala, J. R.; Feygin, A.; Radhakrishnan, S. K. Disabling the Protease DDI2 Attenuates the Transcriptional Activity of NRF1 and Potentiates Proteasome Inhibitor Cytotoxicity. Int $\mathrm{J} \mathrm{Mol}$ Sci 2020, 21 (1).

(30) Siva, M.; Svoboda, M.; Veverka, V.; Trempe, J. F.; Hofmann, K.; Kozisek, M.; Hexnerova, R.; Sedlak, F.; Belza, J.; Brynda, J.et al. Human DNA-Damage-Inducible 2 Protein Is Structurally and Functionally Distinct from Its Yeast Ortholog. Sci Rep 2016, 6, 30443.
(31) Kumar, S.; Suguna, K. Crystal structure of the retroviral protease-like domain of a protozoal DNA damage-inducible 1 protein. FEBS open bio 2018, 8 (9), 1379.

(32) Trempe, J. F.; Saskova, K. G.; Siva, M.; Ratcliffe, C. D.; Veverka, V.; Hoegl, A.; Menade, M.; Feng, X.; Shenker, S.; Svoboda, M.et al. Structural studies of the yeast DNA damage-inducible protein Ddil reveal domain architecture of this eukaryotic protein family. Sci Rep 2016, 6, 33671 .

(33) Chowdhury, A.; Katoh, H.; Hatanaka, A.; Iwanari, H.; Nakamura, N.; Hamakubo, T.; Natsume, T.; Waku, T.; Kobayashi, A. Multiple regulatory mechanisms of the biological function of NRF3 (NFE2L3) control cancer cell proliferation. Sci Rep 2017, 7 (1), 12494.

(34) Jafari, R.; Almqvist, H.; Axelsson, H.; Ignatushchenko, M.; Lundback, T.; Nordlund, P.; Martinez Molina, D. The cellular thermal shift assay for evaluating drug target interactions in cells. Nat Protoc 2014, 9 (9), 2100.

(35) Martinez Molina, D.; Jafari, R.; Ignatushchenko, M.; Seki, T.; Larsson, E. A.; Dan, C.; Sreekumar, L.; Cao, Y.; Nordlund, P. Monitoring drug target engagement in cells and tissues using the cellular thermal shift assay. Science 2013, 341 (6141), 84.

(36) Martinez Molina, D.; Nordlund, P. The Cellular Thermal Shift Assay: A Novel Biophysical Assay for In Situ Drug Target Engagement and Mechanistic Biomarker Studies. Annu Rev Pharmacol Toxicol 2016, 56, 141

(37) Kaldor, S. W.; Kalish, V. J.; Davies, J. F., 2nd; Shetty, B. V.; Fritz, J. E.; Appelt, K.; Burgess, J. A.; Campanale, K. M.; Chirgadze, N. Y.; Clawson, D. K.et al. Viracept (nelfinavir mesylate, AG1343): a potent, orally bioavailable inhibitor of HIV-1 protease. J Med Chem 1997, 40 (24), 3979.

(38) Jarvis, B.; Faulds, D. Nelfinavir. A review of its therapeutic efficacy in HIV infection. Drugs 1998, 56 (1), 147.

(39) Driessen, C.; Kraus, M.; Joerger, M.; Rosing, H.; Bader, J.; Hitz, F.; Berset, C.; Xyrafas, A.; Hawle, H.; Berthod, G.et al. Treatment with the HIV protease inhibitor nelfinavir triggers the unfolded protein response and may overcome proteasome inhibitor resistance of multiple myeloma in combination with bortezomib: a phase I trial (SAKK 65/08). Haematologica 2016, 101 (3), 346.

(40) Driessen, C.; Muller, R.; Novak, U.; Cantoni, N.; Betticher, D.; Mach, N.; Rufer, A.; Mey, U.; Samaras, P.; Ribi, K.et al. Promising activity of nelfinavir-bortezomib-dexamethasone in proteasome inhibitor-refractory multiple myeloma. Blood 2018, 132 (19), 2097.

(41) Hitz, F.; Kraus, M.; Pabst, T.; Hess, D.; Besse, L.; Silzle, T.; Novak, U.; Seipel, K.; Rondeau, S.; Studeli, S.et al. Nelfinavir and lenalidomide/dexamethasone in patients with lenalidomide-refractory multiple myeloma. A phase I/II Trial (SAKK 39/10). Blood Cancer $J$ 2019, 9 (9), 70.

(42) Morris, G. M.; Huey, R.; Lindstrom, W.; Sanner, M. F.; Belew, R. K.; Goodsell, D. S.; Olson, A. J. AutoDock4 and AutoDockTools4: Automated docking with selective receptor flexibility. J Comput Chem 2009, 30 (16), 2785.

(43) Zhang, N.; Zhao, H. Enriching screening libraries with bioactive fragment space. Bioorg Med Chem Lett 2016, 26 (15), 3594 
bioRxiv preprint doi: https://doi.org/10.1101/2020.05.03.075572; this version posted May 5, 2020. The copyright holder for this preprint (which was not certified by peer review) is the author/funder. All rights reserved. No reuse allowed without permission.

\section{Extended Data Table 1. Oligos used in this study}

\begin{tabular}{|c|c|c|c|}
\hline Usage & Gene & F-primer & R-primer \\
\hline \multirow[t]{5}{*}{ qPCR } & PSMA3 & GAAGAAGCAGAGAAATATGCTAAGG & GGCTAAATAGTTACATTGGACTGGAG \\
\hline & PSMC1 & TTCCGAGTTGCTGAAGAACA & ATCCATCCAACTGGTTCAGC \\
\hline & PSMC4 & GGACATCGGAGGCATGGAC & GGTGGGCCATACATGAGGAC \\
\hline & PSMD12 & GTGCGCGACTGACTAAAACA & TAGGCAGAGCCTCATTTGCT \\
\hline & GAPDH & ATGGGGAAGGTGAAGGTCG & ATGGGGAAGGTGAAGGTCG \\
\hline \multirow[t]{2}{*}{ sgRNA } & DDI2 1\# & \multicolumn{2}{|l|}{ GCTGGATTGTCCAAGCCCTG } \\
\hline & DDI2 2\# & \multicolumn{2}{|l|}{ GTGTAACATAATGAGACTGG } \\
\hline \multirow[t]{2}{*}{ clone } & NFE2L1 & ATGCTTTCTCTGAAGAAATACTTAAC & СTTTCTCCGGTCCTTTGG \\
\hline & DDI2 & ATGCTGCTCACCGTGTACTGTGTGC & $\begin{array}{l}\text { TCATGGCTTCTGACGC } \\
\text { TCTGCATCC }\end{array}$ \\
\hline
\end{tabular}


A

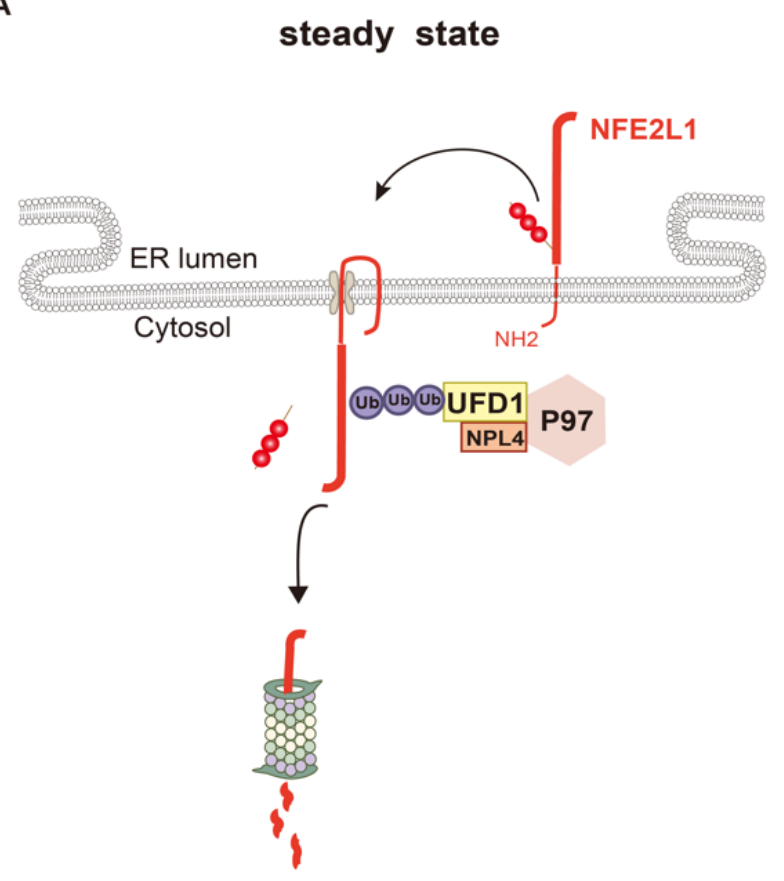

proteasome inhibition

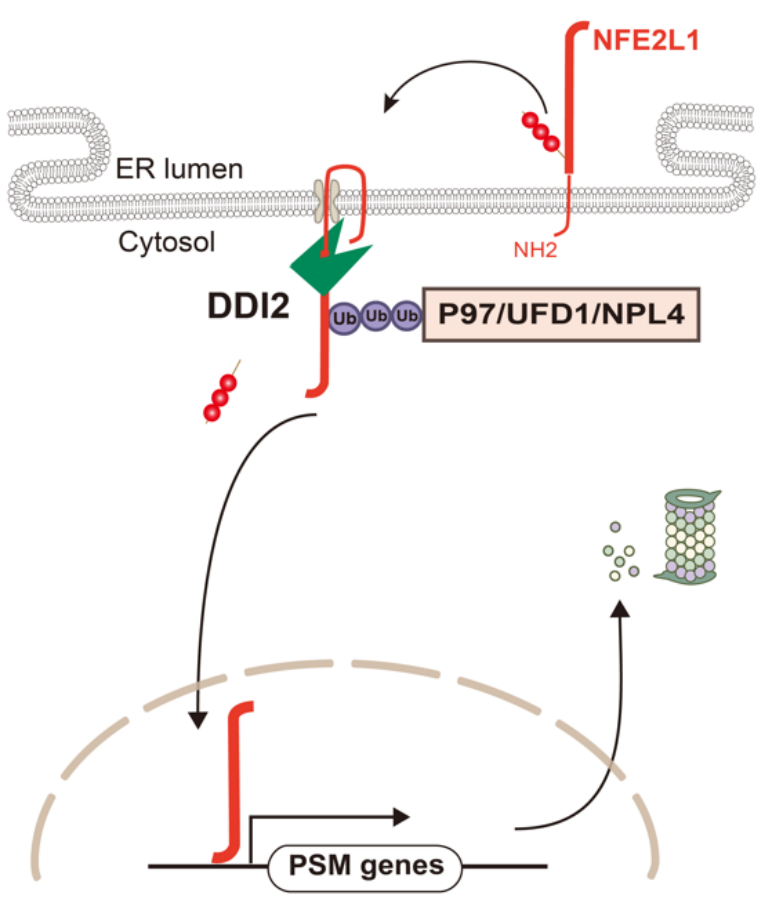

Nucleus

Extended Data Figure 1. Activation of NFE2L1 and compensatory proteasome synthesis. UFD1: Ubiquitin recognition factor in ERassociated degradation protein 1; NPL4: Nuclear protein localization protein 4 homolog; Ub: ubiquitin; PSM genes: proteasome subunit genes. 
bioRxiv preprint doi: https://doi.org/10.1101/2020.05.03.075572; this version posted May 5, 2020. The copyright holder for this preprint (which was not certified by peer review) is the author/funder. All rights reserved. No reuse allowed without permission.

A
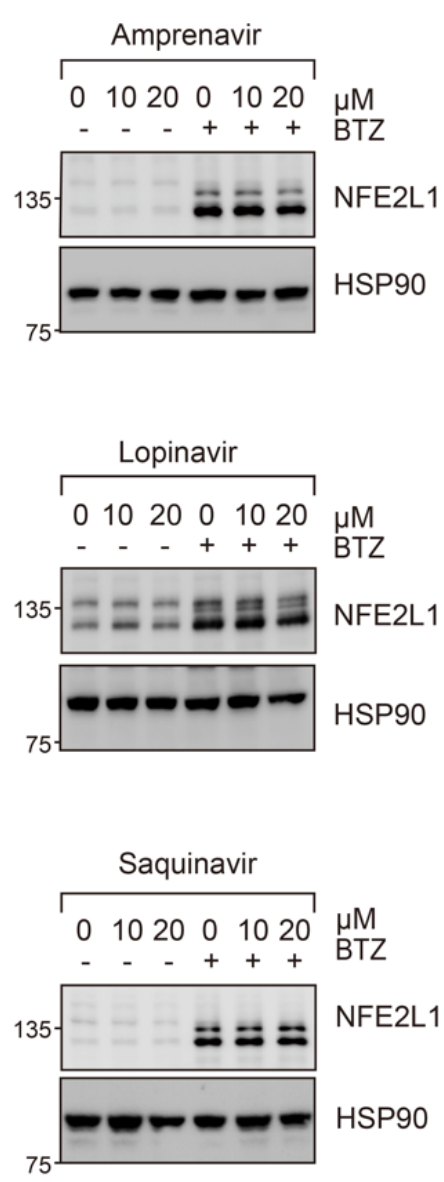
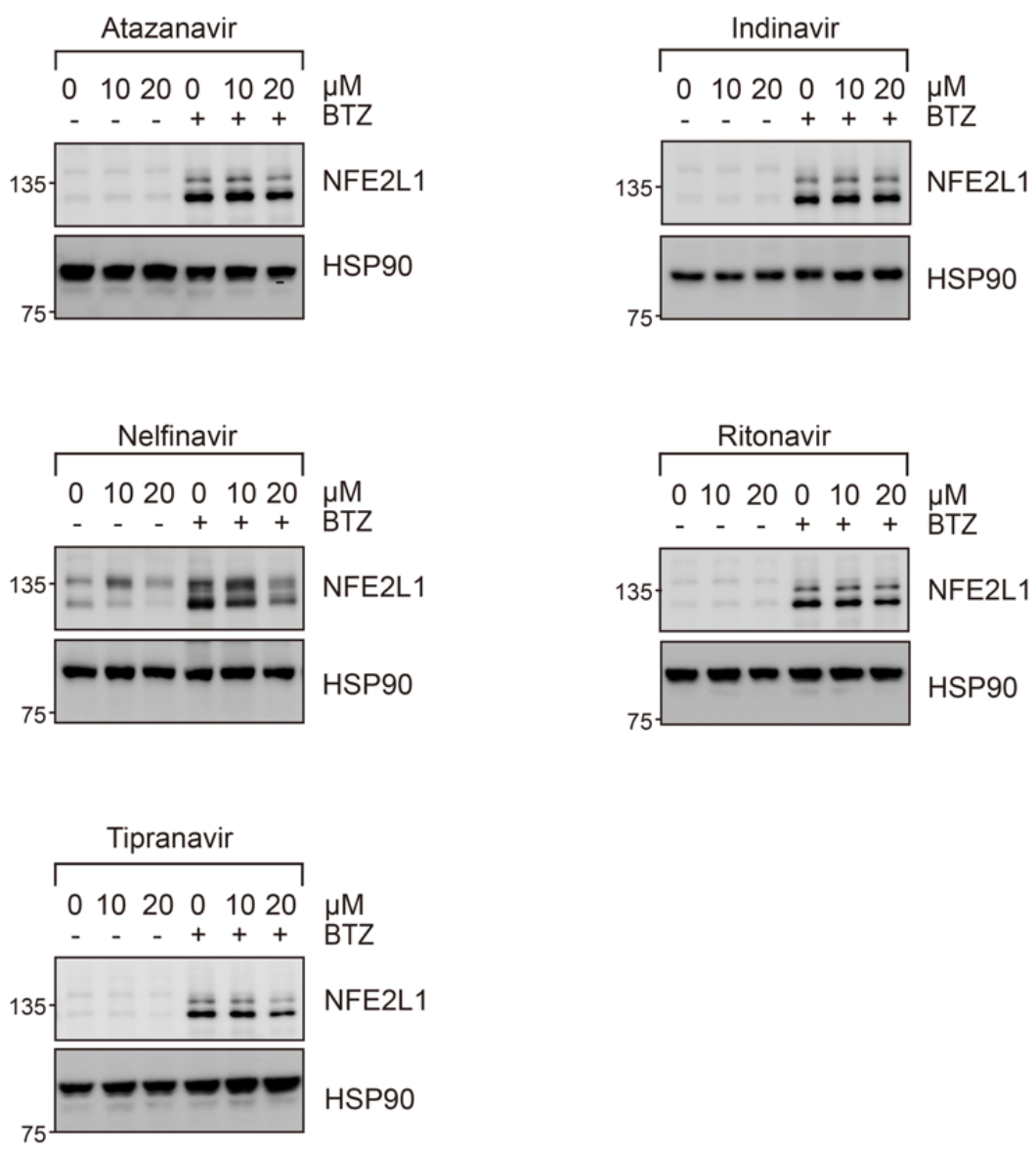

Extended Data Figure. 2. Representative immunoblotting results used in Fig 1C. 
bioRxiv preprint doi: https://doi.org/10.1101/2020.05.03.075572; this version posted May 5, 2020. The copyright holder for this preprint (which was not certified by peer review) is the author/funder. All rights reserved. No reuse allowed without permission.

A

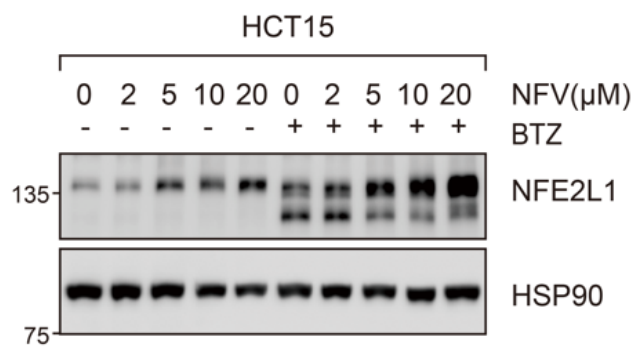

C

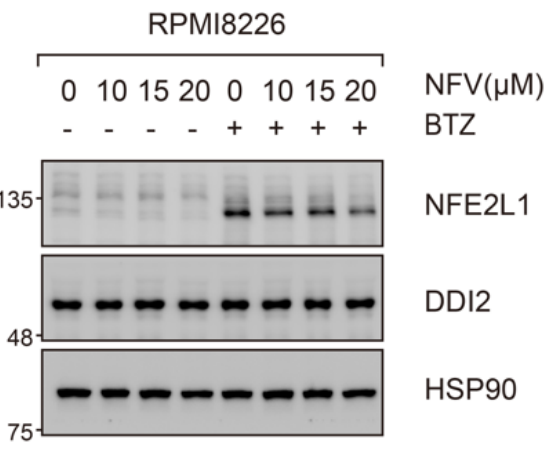

HCT116
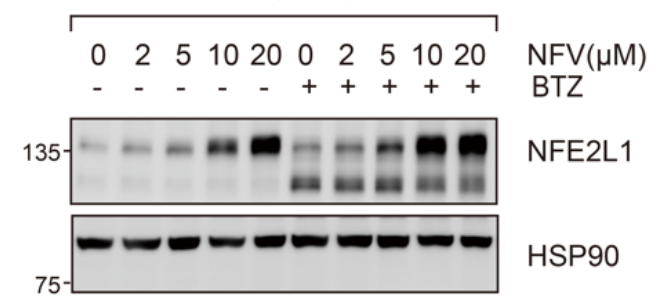

D

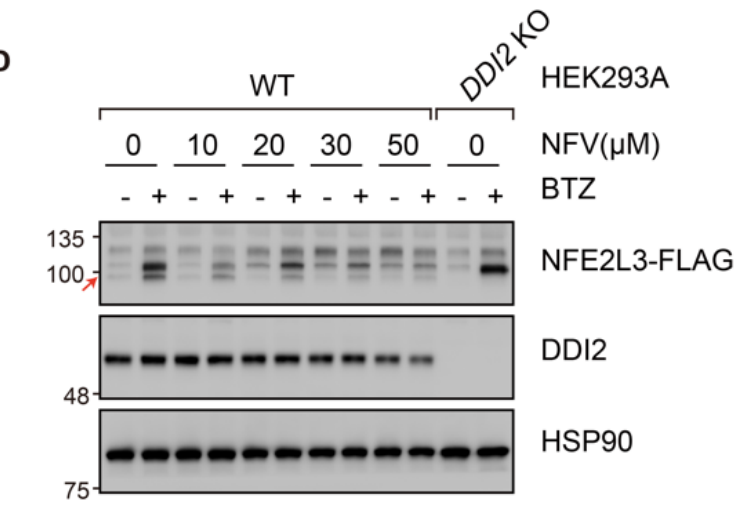

Extended Data Figure. 3. NFV inhibits NFE2L1 activation in different cancer cells, as well as NFE2L3 processing in HEK293A cells. NFV inhibited NFE2L1 cleavage upon proteasome inhibition in HCT15 (A), HCT116 (B) and RPMI8226 (C) cells. Cells were treated with different doses of NFV for $24 \mathrm{~h}$. BTZ (100 nM) was added for $2 \mathrm{~h}$ before cells were harvested. (D) NFV inhibited the processing of NFE2L3. HEK293A overexpressing NFE2L3-FLAG were treated with different doses of NFV for $24 \mathrm{~h}$ followed by BTZ treatment (100 $\mathrm{nM}$ ) for $2 \mathrm{~h}$, arrow indicated the C-terminal fragment of NFE2L3. 
bioRxiv preprint doi: https://doi.org/10.1101/2020.05.03.075572; this version posted May 5, 2020. The copyright holder for this preprint (which was not certified by peer review) is the author/funder. All rights reserved. No reuse allowed without permission.

A

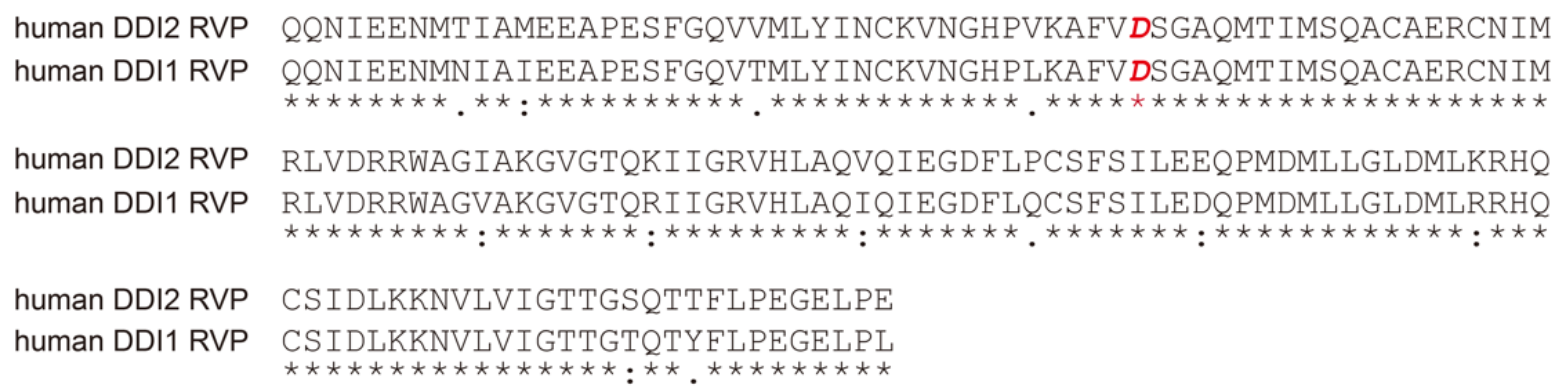

B

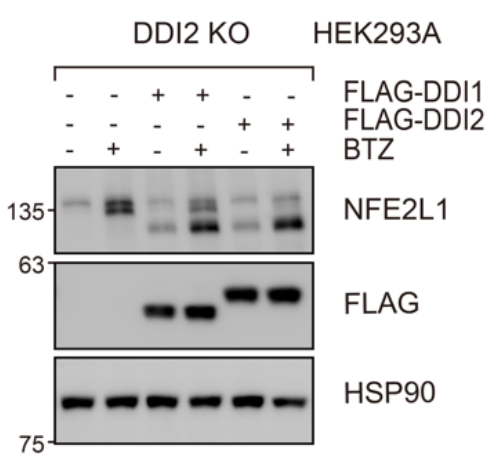

C

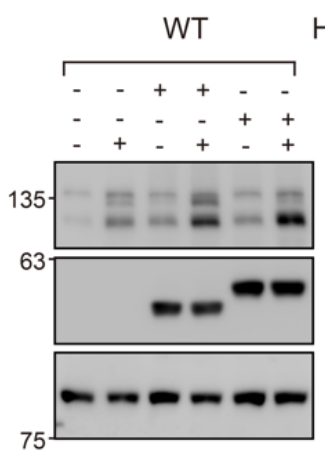

HEK293A

FLAG-DDI1

FLAG-DDI2

$\mathrm{BTZ}$

NFE2L1

FLAG

HSP90
D

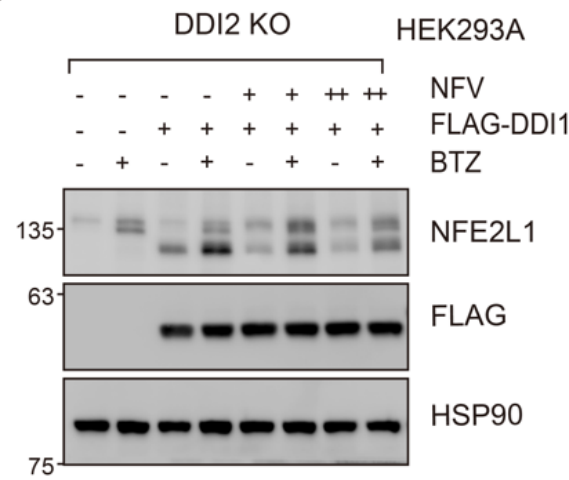

Extended Data Figure. 4. NFV targets human DDI1. (A) Amino acid sequence alignment of DDI1 and DDI2 RVP domain. (B) Ectopic expression of DDI1 in DDI2 KO HEK293A cells restored NFE2L1 cleavage. (C) DDI1 promoted NFE2L1 cleavage as DDI2 did. (D) NFV inhibited the activity of ectopic DDI1 in DDI2 KO HEK293A cells. Cells were treated with $10 \mu \mathrm{M}(+)$ or $20 \mu \mathrm{M}(++)$ NFV for 24 h. BTZ $(100 \mathrm{nM})$ was added $2 \mathrm{~h}$ before cells were harvested. 


\section{A}

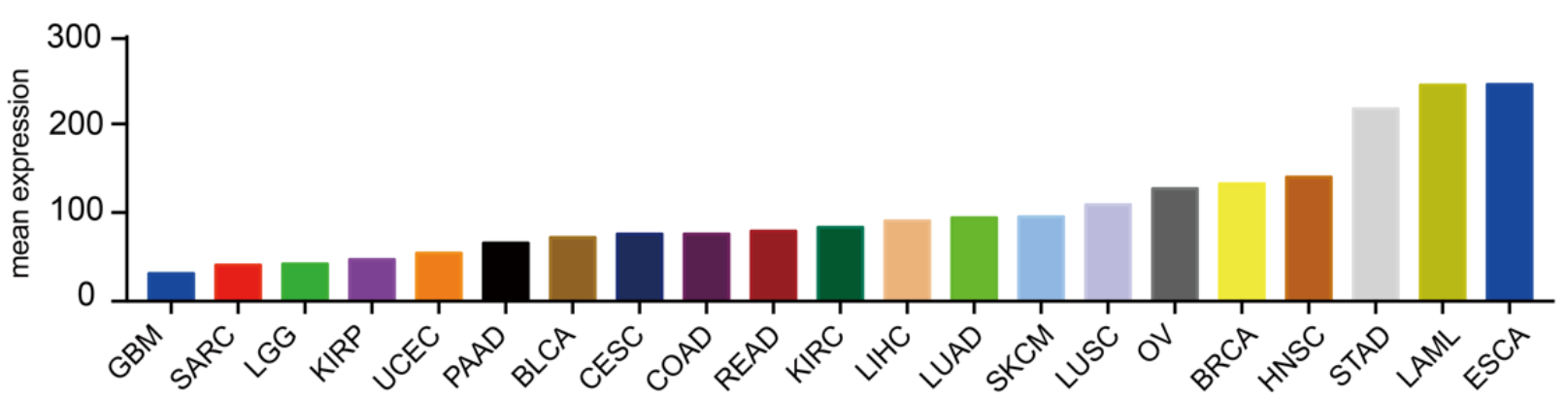

Extended Data Figure 5. (A) Mean DDI2 mRNA level in different cancer types. Data from www.oncolnc.org. BLCA: Bladder Urothelial Carcinoma; BRCA: Breast invasive carcinoma; CESC: Cervical squamous cell carcinoma and endocervical adenocarcinoma; COAD: Colon adenocarcinoma; ESCA: Esophageal carcinoma; GBM: Glioblastoma multiforme; HNSC: Head and Neck squamous cell carcinoma; KIRC: Kidney renal clear cell carcinoma; KIRP: Kidney renal papillary cell carcinoma; LAML: Acute Myeloid Leukemia; LGG: Brain Lower Grade Glioma; LIHC: Liver hepatocellular carcinoma; LUAD: Lung adenocarcinoma; LUSC: Lung squamous cell carcinoma; OV: Ovarian serous cystadenocarcinoma; PAAD: Pancreatic adenocarcinoma; READ: Rectum adenocarcinoma; SARC: Sarcoma; SKCM: Skin Cutaneous Melanoma; STAD: Stomach adenocarcinoma; UCEC: Uterine Corpus Endometrial Carcinoma. 